\title{
MS. DRAUPADI KURU BY TRISHA DAS JUXTAPOSED AGAINST THE DRAUPADI OF THE PALACE OF ILLUSIONS BY CHITRA BANERJEE DIVAKARUNI
}

\section{SIMRAN AGARWAL}

Kanoria PG Mahila Maha Vidyalaya, Affiliated Rajasthan University, Jaipur, India

The Palace of Illusions is a novel by award-winning novelist and poet Chitra Banerjee Divakaruni. It is a critically acclaimed text as it gives an intriguing insight to the feminine side of the otherwise patriarch tale. She highlights the inner recesses of the mind of Draupadi. She narrates the story as seen from the eyes of Draupadi, retelling her joys, desires, adventures and struggle through the voice of Panchaali.

Trisha Das, an award-winning documentary filmmaker is the author of Ms Draupadi Kuru: After the Pandavas. In her book, she unleashes the capability of Draupadi, her strong undertones that hid behind the glorification of her husbands. Her Draupadi is nothing but fearless, unfettered and limitless. Her second life provides for her unruly and boundless attitude. Written in the form of a time-travel historical romance, Ms. Draupadi Kuru by Trisha Das is a completely new story fictionalized around some of the major female characters of the Mahabharata.

Draupadi was destined to bring a change in the history of mankind and the future of Dharma in Bharatavarsh. She is a symbol of strength, virtue, and morality. It was her wrath and anger that lead to the great war at Kurukshrestra.The story of her power and endurance has been re-told in many renditions and retellings of the great epic. In India where woman's indivuality is valued far less to that of a male species, the above mentioned authors have tried to give the women of ancient India power and freedom in their extraordinary writing.

This paper analyzes and contrasts the character of Draupadi in The Palace of Illusions and Ms. Draupadi Kuru : After the Pandavas. In order to bring out the differences and similarities of the sketch of Draupadi in both the texts, the paper focuses on various aspects of a novel such as the writing style, the themes, the characters and the motive of the respective authors. These parts of the novels impact and shape the character of Draupadi and bring out the juxtaposition of the same character in two different stories.

KEYWORDS: Character, Comparision, Draupadi \& Juxtaposition
\end{abstract}

Received: Apr 13, 2020; Accepted: Jun 03, 2020; Published: Jun 12, 2020; Paper Id.: IJELAUG20201

\section{INTRODUCTION}

Published in 2008 by Picador, The Palace of Illusions is an award-winning novel, a critically acclaimed text which gives an intriguing insight to the feminine side of the otherwise patriarch tale. Chitra Banerjee Divakaruni presents the characters as human as possible, devoid of the aura of divinity unlike the other fictional renditions of the epic. She narrates the story as seen from the eyes of Draupadi, retelling her joys, desires, adventures and hstruggle through the voice of Panchaali.

Published in 2016 by Harper Collins, Ms Draupadi Kuru: After the Pandavas written by Trisha is a completely new story around the major female characters of Mahabharata, i.e., Draupadi, Gandhari, Kunti and Amba. It is a completely new fictional story weaved out of the characters from the past with contemporary concerns 
and setting. She is nothing but imaginative throughout the course of the book. Hence, she has provided a completely fresh start to Draupadi.

Draupadi is well-known iconoclastic mythical figure, belonging to the famous Hindu epic Mahabharata. Also, known as the Panchaali, she was the principal wife of the Pandavas, married to each one of them. Born out of fire, Draupadi was destined to bring a change in the history of mankind and the future of Dharma in Bharatavarsh. She is a symbol of strength, virtue, and morality. It is her wrath and anger that leads to the great war at Kurukshrestra.

While Banerjee narrates the story from the perspective of Draupadi herself, Das weaves a completely new tale around the character, picturing her in the contemporary Delhi. The motto of the paper is to analyze and contrast the character of Draupadi in Palace of Illusion and Ms. Draupadi Kuru after the Pandavas. In order to understand the differences and similarities of the sketch of Draupadi in both the texts, we need to focus on various aspects of a novel such as the writing style, the themes, the characters and the motive of the respective authors.

\section{MOTIVE OF THE AUTHOR}

The Palace of Illusion is a re-telling of the Mahabharata through the voice of Draupadi. While majority of the authors have tried to glorify the warfare and philosophy of the epic, Chitra Banerjee Divakaruni highlights the inner recesses of the mind of Drapaudi. It exposes the story from Drapaudi's perspecitve, retelling the joys, the mysteries, the adventures and the war through the voice of Panchaali.

Her objectives with the book reflect in her sketch of the Draupadi. With author sticking to the retelling of the tale, we observe Draupadi is a modernist in her thoughts, but at the same time she is a byproduct of her era. The writing is successful in giving the women of ancient India (here Draupadi) power and freedom of emotions, though the retelling of the epic limits her action. The story binds the character to her destiny and fate, inescapable from her dreadful future and lone death. She is able to focus on the issues of the woman; however they date back to the epoch of Draupadi itself. Hence, the Draupadi in The Palace of Illusions has been projected as a strong woman with modernist thought and vision, however, her voice echoes only in her mind and she is unable to reciprocate the same in her actions. She is a feminist at heart, but her patriarchal setting does not provide for her freedom of action.

“ "And who decided that a woman's highest purpose was to support men ?" I burst out as soon as we were alone. “A man, I would wager ! Myself, I plan on doing other things with my life." '(Divakaruni 26)

The retelling thus brings out the strength of Draupadi and her journey to heroism. It explores her inner desires with her yearning towards Karna, her anger towards the patriarchy, her vengeance, scuffle while keeping the epic alive. But the character falls short of modern action and drama.

Trisha Das on the other hand, has written a completely new story around the major female characters of Mahabharata, i.e., Draupadi, Gandhari, Kunti and Amba. Unlike The Palace of Illusions, it is a completely new fictional story weaved out of the characters from the past with contemporary concerns and setting. The objective of her writing was to give a second chance to the characters, where they proclaim their own destinies and have the freedom to act to their minds.

In an Interview upon the release of her book she said, 
"In Mahabharata, most of the women characters — be it Draupadi, Kunti, Amba or Gandhari — are presented as victims, their lives unfulfilled. If only they got a second chance to enjoy life..."

Her motive is clearly reflected in her writing. She is nothing but imaginative throughout the course of the book. Hence, in line with her objectives, she has provided a completely fresh start to Draupadi. She reigns in her impatience and curious attitude to speak for the contemporary issues. She unleashes the capability of Draupadi, her strong undertones that hid behind the glorification of her husbands. Her Draupadi is nothing but fearless, unfettered and limitless. Her second life provides for her unruly and boundless attitude.

Draupadi seeks for answers and in order to do so, takes the destiny in her own hands, unlike the epic (wherein she depended on her husbands). She explores the technology of the earth with awe and curiosity and speaks for the cause of Vaishali (a rape victim) with an unabashed confidence and heart wrenching empathy. In the epic, where she fails to protect herself from the assault, in this new drama, she acts as a leader for the group and is careful of Amba and Zafar's relationship. She takes the responsibility of the four of them and makes sure their mini-adventure runs smoothly and painfree.

The tale puts forward Draupadi's curiosity, her leadership and her feisty attitude. It definitely gives a chance to the character to do something on her own for the women rather than depending on her husbands to fight for her. The objective of the author hence forms the foundation of the character.

The writing is able to allow for the amends of the past, which make Draupadi, Kunti and Amba to give up heavens and choose life over it. While in Palace of Illusions, the patriarchy limit Draupadi's action and she is unable to take charge; here she impacts millions of women through her debut on the television. While Banerjee is able to bring out the voice of the Panchaali, in Das' writing Draupadi's voice is actually able to make a difference.

The motives of both the authors present a strong, fierce and impatient heroine. Her actions and her issues fall under same genre; however differentiate in terms of their epoch. The Draupadi of The Palace of Illusion is concerned with her revenge, her desires, her destiny and building her identity, while ageing and gaining experience over the course of the story; the Draupadi of the Trisha Das' book, is a developed mature woman who wants to transform her established identity from her previous life. However, both of the characters struggle with their choices; have feisty attitude and lack patience.

\section{WRITING STYLE}

The Palace of illusion is a retelling of Mahabharata. It is written in first person narration by Draupadi presenting the character of Draupadi as human as possible. She is kept bereft of her aura of divinity, thus associating the human reader with the protagonist; the Panchaali. Thus, the ancient character of Draupadi has been remolded into a woman with a modern mind grappling with vogue issues of identity, individuality and isolation.

'The princess who longed for acceptance, the guilty girl whose heart wouldn't listen, the wife who balanced her five-fold role precisely, the rebellious daughter-in-law, the queen who rules in the most magical of the palaces, the distracted mother, the beloved companion of Krishna, who refused to learn the lessons he offered, the woman obsessed with vengeance-None of them were the true Panchaali. If not who was I?' (Divakaruni 229)

The lucid style of work, with symbols of modernism and play of the paradoxes, generates a relationship between contemporary reader and the classic character. Though the work is compact, it encloses various sides of Draupadi, her ego, 
love, freedom, sex, desires and marriage. The writing style thus renders the character as ordinary as today's metropolitan woman struggling with her marriage and identity and the entrenched patriarchy of the society.

On the other hand, written in the form of a time-travel historical romance, Ms. Draupadi Kuru by Trisha Das is a completely new story fictionalized around some of the major female characters of the Mahabharata. The story seems to be based on the author's knowledge of the Mahabharata and does not delve into details of the epic. Hence the character of Draupadi undergoes a change while adapting to the modern settings and bearing cultural and technological shock.

'Draupadi looked around eagerly, trying to take in as much as possible. All the people she saw, apart from the identical dressed children, were dressed very differently from each other. In her day, everyone, men and women, had worn different versions of the sari,a cloth draped over the shoulder with a belted cloth draped and tied over the groin and legs, with a small breast-cloth for women. But, as Draupadi observed, there seem to be no prescribed dress code in these times.' (Das 46)

The Humor has been beautifully amalgamated with the imagination, bringing out the best and worst of Draupadi from a fresh perspective. To say, the occasional fights between Gandhari and Draupadi; the two distinct characters of Mahabharata fighting like cats and dogs, not only is hilarious but speaks for her temper. Her careful inspection of Zafar's office, highlight her curiosity, while her protective attitude towards Amba renders her a completely different avatar.

\section{CHARACTERS OF THE BOOK}

The Palace of Illusions by Banerjee Divakaruni solely focuses on the dilemmas of the protagonist, giving the stereotypical Panchaali, a fresh breath of air. The story explores the strength of a woman and her self-dependence through the never heard voice of Panchaali. The best thing about the characterization of Draupadi lies in her strength and power. She is not a pitiable character, but a fictional woman with abundance of perseverance. Though she has her shades of grey and white, her sketch has been brilliantly brought to the surface. Rather than rendering divinity; Draupadi's contriving mind, her pride, her jealousy, her constant battle with herself, etc. all detail out the presence of ordinary woman.

'The more people dissuaded me, the more determined I became. Perhaps that has always been my problem to rebel against the boundaries prescribed for woman.' (Divakaruni 343)

Though there is a visible radicalism in her thoughts, her actions conform to the ancient setting. A rebellion in mind, a prominent queen with strong will and unabashed desires, she strictly binds herself to her destiny and prophecies around her. An unapologetically complicated character, the retelling of the story displays her as a victimized martyr.

The character of Draupadi is in constant search for identity, trying to reinvent her individuality and self while conforming to her fate. Though the outlook concerns modern sensibilities, the character adheres to the ancient setting and performs within her scope. Hence, the rendition by Banerjee lacks the necessary action on the part of Draupadi.

Further, the story tries to bring out the reactions of other fellow characters, but their limited exploration and scattered sketches, makes it difficult upon the readers to grasp their thoughts. Thus the story remains restricted to the mind of Panchaali and her thoughts while the reader struggles with the world outside her mind.

The book Ms. Draupadi Kuru by Trisha Das, on the other hand has an ominous narration following the story of the after lives of Amba, Gandhari and Kunti as well. Bored of the comforts and pace of heaven, Draupadi wishes to relive human life. While Kunti wishes to do away her long borne guilt of abandoning Karna, Amba rides along in order to 
experience the womanhood, she lost in her previous life.

Through the plethora of female characters at hand, she exploits each one of them to unravel the various feminist undertones during the course of the story. While the epic of Mahabharata portrays Draupadi as a victim, this new tale presents her as a fiery and bossy self; in charge of the visit and safety. A completely different perspective has been put forward, where she has been given a freedom of choice, a voice as well as ownership of her mind and body.

'All of us women were hurt and used by men who were too busy chasing their own ambitions to give any thought to us. So I wonder sometimes, when will it be our chance to find some happiness? Don't we have the right to try and do things for ourselves after spending the whole of our mortal lives sacrificing for others?' (Das 21)

While the character of Draupadi is a celebration of a strong woman, with the ability to fight for her cause, the character of Amba explores the desires of a woman, with her affair with Zafar. Kunti takes a lead on motherhood with her determined mind to take up Karan on the right path, the character of Gandhari infuses much-needed humor. Hence each character has been assigned a different motive, each one bringing out a distinct attribute. Hence, we can say the multiplicity of characters bring to light diverse feminist undertones, unlike Banerjee Divakaruni's Palace of Illusions with only shades of grey and white of Paanchali alone.

However, in a similar fashion, her Draupadi is a proud, impatient and overbearing character with tints of sympathy and contemplation. She is a woman with courage, able to speak not only for herself but for others. The famous monologue of the epic is here replaced with her audition speech with Vaishali; but it highlights the very same agonies of a woman; though in a more relevant manner in regard to the contemporary setting.

Her physical attributes also share a common ground with a dark skin tone, long black hair and a radiant personality. She stands strong for the cause of woman even in heaven demanding for a female tribunal, which is quite similar to Draupadi's fictional tribunal for the widows of the war in Banerjee's Palace of Illusion. She is a free spirit and her courage has been exploited to the core; to say the least.

However, on the contrary her actions speak for her fate rather than the external prophecies. From the beginning of the book, she is determined to take charge. Her way with her words put all the female characters into action and even convinces Krishna to grant for her visit. She does not let Gandhari take control over their expedition, saves Amba from getting assaulted, rescues Karan from getting shot, puts up with her Pilot episode, and lastly takes a call on her rebirth.

She also draws from the epic to put forward her previous life and her plight. She calls in for her failure as a mother, her strenuous marriage and her imprisoned childhood as a princess. Time and again, she compares the era, in order to put in perspective of the progress and regression from the past. Her pain is bought out when she feels empathetic with Vaishali; thus keeping it true to her previous life.

Further, the contrast between her character of Sania (an educated modern day metropolitan ambitious firl), and Draupadi emphasize upon the journey of struggles of women over the centuries for her rights and her voice, from the time of Draupadi to the present day. The cultural shock borne by Draupadi upon her visit has been beautifully brought forward by Das, giving her a curious and keen identity.

“ "But I intend on discovering more about this world. I have so many questions that need answers." She began to pace again. "Where are all the birds? There have to be somewhere because I can see their droppings everywhere. Why was 
it so freakishly cold inside that eating? Why everyone is in such a hurry? How do people climb up and down in those tall buildings? And, most importantly -"she twisted uncomfortably-" How do I take off this damned bra?" ' (Das 94)

\section{THEMES}

The Palace of Illusion explores the themes of identity and self from the very beginning, from the prophecy of Draupadi's birth until her final moments in an introspective conversation with Krishna. During the course of the novel, the author indirectly takes the readers on a journey of self-exploration. Constantly in search of meaning of her life, Draupadi ultimately finds her answers with her death.

Other than the theme of exploration of self, ample emphasis has been laid upon desires of a woman, with the plot of Karna and Draupadi in the background. Draupadi's longing for Karna is a bold fictional perspective put forward by Banerjee Divakaruni. It paves way for exploration of Draupadi's sexuality and womanhood. The theme of desire and sexuality renders the Divakaruni's Draupadi human and ordinary.

Draupadi's modern mind also pushes for gender equality in regard to subjects of education, marriage and power; however the primal settings limit the protagonist. Thus, there are hints of gender equality scattered in the novel, however it is not scrutinized enough. The character of Draupadi throws light on different relationships of a woman, as a friend, sister, wife, mother, daughter, queen and a leader. Hence, the character glorifies womanhood in all its glory. The themes of war, caste and valour are dialed down, unlike the original epic.

Similarly, the book by Trisha Das celebrates womanhood; however each character puts forward a distinct feature of the broad theme. While the character of Draupadi is a celebration of a strong woman, with the ability to fight for her cause, the character of Amba explores the desires of a woman, with her affair with Zafar. Kunti takes a lead on motherhood with her determined mind to take up Karan on the right path.

The character of Draupadi also highlights the plight of woman in the modern society, while she compares her era to the present times. The character of Sania highlights the modern day woman, with her ideas of independence, freedom and gender equality. The contrast between her character and Draupadi emphasize upon the journey of struggle of woman for her rights and her voice.

'And she was proud of that. She might have been a failure in everyone else's eyes but she would be damned if their opinions made her think any less of herself. She had qualities that were admired, even worshipped in men; courage, initiative, rational thought, vision. If more women in her time had been like her, then perhaps her life would have been different.' (Das 69-70)

However certain side plots and incidents and emphasize on the victimization of woman; similar to the times Draupadi was acquainted with. In the face of feminism, Das skillfully emphasizes on issues such as the entrenched patriarchy and the view of daughters as a burdensome responsibility rather than individuals. The contemporary world has given her voice and freedom of action but still looks onto a woman with the same glasses. Her identity is still attached with her marital status, her appearance linked with her worth and her body is still considered as an inanimate object to exploit.

The theme of human life forms the foundation of the plot. The desire to feel the rush of mortality is what inspires Draupadi to embark on her mini-vacation. The story is full of description of the mortal world, in all its beauty and ugliness. The Draupadi applaudes the human progress and advancement, she is fearless in attacking the society for its lack of ethos 
and the monstrosity of the very same technology. The theme taps on Draupadi's curiosity and excitement, while it also brings in her contempt at the degeneration of human morality and standards.

'Inside the house, where they belong...I can see that even while mankind has scaled the skies to live among the birds, has conquered disease and discomfort, has made advancements that would seem unfathomable and unimaginable to someone from the previous age. Not much has changed for womankind.' (Das 159)

Hence, Draupadi speaks for the change; reigning in the modern thought while contrasting it to the bygone epoch, drawing out the similarities and differences in the bygone times and the modern day. She also speaks for the cause of woman and makes a difference; even if it means that she has to give up the heavens. Hence, Draupadi acts as the model for independent womanhood, as an individual.

\section{CONCLUSIONS}

The Palace of Illusion is a re-telling of the Mahabharata through the voice of Draupadi. Chitra Banerjee Divakaruni highlights the inner recesses of the mind of Drapaudi. The tale which has always been a symbol of Dharma and war, Banerjee's rendition of the epic has made it a symbol of womanhood with her character of Draupadi. Her Motives for the epic provide Draupadi, a voice.

Trisha Das on the other hand, has written a completely new story around the major female characters of Mahabharata, i.e., Draupadi, Gandhari, Kunti and Amba. She unleashes the capability of Draupadi, her strong undertones that hid behind the glorification of her husbands. Her Draupadi is nothing but fearless, unfettered and limitless. Her second life provides for her unruly and boundless attitude.

In the Palace of illusion, the ancient character has been remolded into a woman with a modern mind grappling with vogue issues of identity, individuality and isolation. It encloses various sides of Draupadi, her ego, love, freedom, sex, desires and marriage. On the other hand, in Ms. Draupadi Kuru by Trisha Das, she acts as the model for independent womanhood, as an individual. The character of Draupadi undergoes a change while adapting to the modern settings and bearing cultural and technological shock.

The Palace of Illusion explores the themes of identity and self. Constantly in search of meaning of her life, Draupadi ultimately finds her answers with her death. Draupadi's longing for Karna is a bold fictional perspective put forward by Banerjee Divakaruni. It paves way for exploration of her sexuality and womanhood. Similarly, the book by Trisha Das celebrates womanhood. The book also brings out the theme of human life which forms the foundation of the plot.

In The Palace of Illusions by Banerjee Divakaruni is a rather slanted tale in the voice of Draupadi. The book solely focuses on the dilemmas of the protagonist, giving the stereotypical Panchaali, a fresh breath of air. She is not a pitiable character, but a fictional woman with abundance of perseverance and patience. Though there is a visible radicalism in her thoughts, her actions conform to the ancient setting. A rebellion in mind, a prominent queen with strong will and unabashed desires, she strictly binds herself to her destiny and prophecies around her. An unapologetically complicated character, the retelling of the story displays her as a victimized martyr.

However, on the contrary in the writing of Das, her actions speak for her fate rather than the external prophecies. She is a free spirit and her courage has been exploited to the core; to say the least. Though her physical attributes also share 
a common ground with a dark skin tone, long black hair and a radiant personality, this new tale presents her in a fiery and a modern avatar, where she has been given a freedom of choice, a voice as well as ownership of her mind and body.

\section{REFERENCES}

1. Divakaruni Banerjee C. “The Palace of Illusion”. Picador, India 2009.

2. Trisha Das. "Ms. Draupadi Kuru : After the Pandavas ”. Harper Collins, 2016.

3. "Draupadi Returns With a Vengeance". Taylor\&Francis, 2020,https://www.tandfonline.com/doi/abs/10.1080/17449855.2019.1566160.

4. "On An Epic Holiday". The Hindu, 2020, https://www.thehindu.com/books/On-an-epic-holiday/article14649773.ece.

5. Geetha, P. "Narrative Technique in Shashi Deshpandes Novels." International Journal of Linguistics and Literature (IJLL) 7. 6, Oct - Sep 2018; 1-8

6. "Kama's Last Sutra: Novelist Trisha Das In Conversation". Fair Observer, 2020, https://www.fairobserver.com/region/central south asia/trisha-das-author-interview-kamas-last-sutra-india-culture-news198171.

7. Nanda, Silima. "Revolting Gender in Pratibha Ray's Yagnaseni and Mahasweta Devi's Draupadi." International Journal of English and Literature (IJEL) 8. 6, Dec 2018, 87-90 @ TJPRC Pvt. Ltd.

8. PARMAR, Surabhi A.. Ms Draupadi Kuru: Re interpreting the Women from the Mahabharata. SMART MOVES JOURNAL IJELLH, [S.l.], v. 5, n. 10, p. 9, oct. 2017. ISSN 2582-3574. Date accessed: 15 May 2020.

9. Chander, Rajesh. "Women Through the Indian Traditions." International Journal of History and Research (IJHR) 5. 4, Dec $2015,1-8$

10. Joell.In, 2020, http://joell.in/wp-content/uploads/2020/03/111-114-RECREATING-THE-FEMALE-IDENTITY.pdf.

11. Chakraborty, Sayantika Bose, and Saptorshi Das. "Nalayani: An Immortal Saga of Femininity and Feminism." International Journal of English and Literature (IJEL) 9. 2, Apr 2019, 1-6 